\title{
Research
}

\section{How Effective is the Buffer Zone? Linking Institutional Processes with Satellite Images from a Case Study in the Lore Lindu Forest Biosphere Reserve, Indonesia}

\author{
Marion Mehring $^{1,2,3}$ and Susanne Stoll-Kleemann ${ }^{1}$
}

\begin{abstract}
Biosphere reserves seek to reconcile nature conservation with local development goals, for example by delineating buffer zones of sustainable resource use around core areas with primary conservation objectives. Here we evaluate buffer zone effectiveness in reducing deforestation within the Lore Lindu Biosphere Reserve in Sulawesi, Indonesia. Socio-economic and remote-sensing data were combined in an integrated approach. We applied a systematic qualitative social research design and carried out in-depth interviews with local, sub-national, and national authorities. Data collected through the interviews were used to interpret satellite images: (1) spatially, that is, forest cover change in the buffer zone versus the core area and, (2) over time, that is, forest cover change as a response to changing management regimes and socio-economic processes in the region. For this purpose a time series of LANDSAT scenes from 1972 to 2007 was used to classify homogeneous areas of forest cover to detect deforestation. According to the satellite image analysis, the buffer zone in Lore Lindu was ineffective at reducing forest cover clearing in the core area between 1972 and 2007. Since management establishment in 1998, the deforestation rate within the core area even increased fourfold. The gathered data suggest that there are three main institutional drivers to account for this ineffectiveness: (1) Low awareness of boundary demarcation among the villagers due to the lack of participation during management and boundary establishment, (2) The fall of the national president Suharto in 1998, which subsequently triggered deforestation activities in the core area, as the park was perceived to be the local branch of the national, suppressive regime, and (3) The lack of implementation of the biosphere reserve concept at the national level, which leads to unclear responsibilities in the buffer zone as the legal backing for any cooperation in the buffer zone is lacking. Although it appears that the forest status in Lore Lindu is still good compared to other regions in Indonesia, attention must be given to the protection of the core area. We thus conclude that the biosphere reserve concept needs to be strengthened in Indonesia. Its implementation at the national level, including adoption of clearly defined regulations, would substantially contribute to reducing negative impacts on biosphere reserve management through, for example, carefully designed awareness raising programs.
\end{abstract}

Key Words: biosphere reserve; buffer zone; Indonesia; management effectiveness; protected area; remote sensing

\section{INTRODUCTION}

Although the rate of deforestation, at the global scale, has started to decrease slightly, several regions remain where it is still alarmingly high (FAO 2010). Tropical forests are under serious threat from logging and clearing for agriculture (FAO 2010). Thus, in situ conservation strategies, such as protected area (PA) establishment, are required to sustain ecological integrity of forest ecosystems in the future. PAs are perhaps the most important of all conservation tools to reduce deforestation (WWF 2004). There are now more than 130,000 PAs worldwide, covering more than $12 \%$ of the Earth's land surface (WDPA 2010). But designation of PAs is only the first step. If PAs are to be effective in fulfilling their role in biodiversity conservation, they must be well managed (WWF 2004).

The idea to set aside natural areas to maintain their intrinsic values is not a recent phenomenon but has been a human endeavor for millennia (Chape et al. 2005). The establishment of national parks (NPs) and reserves, as understood in the initial western paradigm of PAs, often caused conflicts between the park management and the surrounding people (Chape et al. 2005). Thus, park managers have recognized that the management methods developed in the past no longer suffice (Schonewald-Cox et al. 1992). New approaches in cross-boundary management were needed. Solutions derived from either ecological strategies to broaden PA management to habitat management across administrative boundaries, or anthropogenic techniques, such as cooperation with residents (Schonewald-Cox et al. 1992). The first deliberate international effort that combined both strategies was the UNESCO biosphere reserve (BR) concept (Batisse 1993). BRs evolved as a separate category of PAs, internationally designated by UNESCO, and are now considered separate from other Pas due to the equal emphasis given to development objectives (Ishwaran et al. 2008). The BR model stands out because it takes into account the structure and dynamics of regional landscapes, integrates the concept of ecosystems, and incorporates the presence of human settlements (Guevara and Laborde 2007). The idea of setting up BRs resulted from the UNESCO Conference on Rational Use and Conservation of the Resources of the Biosphere in 1968 (Batisse 1993). The

${ }^{1}$ University of Greifswald, ${ }^{2}$ Institute for Social-Ecological Research (ISOE), ${ }^{3}$ Biodiversity and Climate Research Centre (BiK-F) 
Man and the Biosphere (MAB) program, which directly derived from this conference aimed at reconciling utilization with long-term protection (Batisse 1993). BRs are a visionary category of PAs that include humans (Guevara and Laborde 2007). To date it is the only type of reserve that takes into account in its conservation strategies the biodiversity and cultural diversity of the surrounding area. The implementation of this vision at the local level is realized through zonation of the designated area. BRs are divided into three zones. The core area justifies the creation of the BR and seeks to protect biodiversity. The surrounding buffer zone allows low-impact activities in the form of sustainable land use and has the function of protecting the core area from high human impact. The buffer zone is externally surrounded by the transition area where the focus is on cooperation with local stakeholders. Motivated by this useful concept, an increasing number of PAs such as NPs have established buffer zones according to the BR model (Neumann 1997).

Here we focus on the Lore Lindu Biosphere Reserve (LLBR) in Sulawesi, Indonesia, to evaluate the functional goal of the buffer zone to protect the core area from high human impact activities such as deforestation. In doing so, we use an innovative approach that combines satellite images with findings from interview analysis. Techniques are drawn from approved management effectiveness methodologies (for an overview, see Appendix 1). In particular, we seek to answer two questions: (1) Has the management in LLBR been able to counteract the country-wide trend of increasing deforestation? and (2) Which factors at the local, sub-national, and national level influence deforestation rates in LLBR?

\section{METHODS}

\section{Study site}

The study site is located in the province of Central Sulawesi, Indonesia, south of its capital Palu (Figure 1). As one of seven BRs in Indonesia, LLBR was officially declared a UNESCO Biosphere Reserve in 1977 comprising the five sub-districts Sigi Biromaru, Kulawi, Lore Selatan, Lore Utara, and Palolo (Widagdo 2008). In 1993 the core area of the LLBR was designated as Lore Lindu National Park (LLNP) and was further declared a World Heritage Site by UNESCO (Shohibuddin 2008). However, the official boundary of the core area was not fixed until 1998, when the management body of LLNP was established by the Ministry of Forestry (Widagdo 2008). To date management is carried out by the Balai Taman Nasional Lore Lindu (authority of Lore Lindu National Park), an administrative office under the Ministry of Forestry at the national level (Shohibuddin 2008). In this study, the LLNP authority corresponds to the LLBR authority as the head of the Indonesian MAB program in Jakarta passed the BR responsibility to the LLNP. The term of either LLNP authority or LLBR authority is used depending on whichever term the particular interview partner used. Table 1 depicts the management goals and respective efforts for the area of LLBR.

Fig. 1. Study site: Lore Lindu Biosphere Reserve, Sulawesi, Indonesia. Data source: Stability of Rainforest Margins Project (STORMA), University of Göttingen, Germany; own illustration.

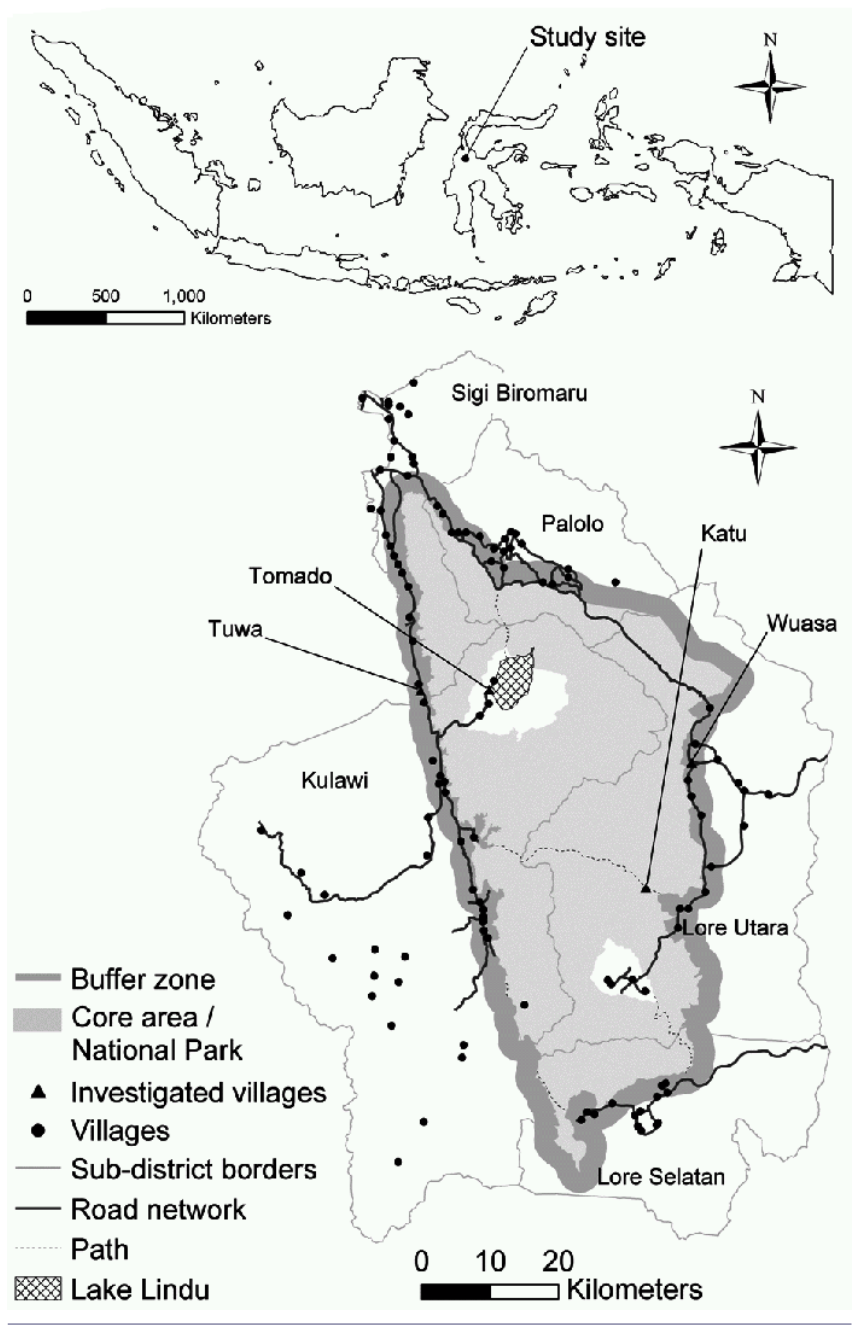

Through regulation 464/Kpts-II/1999, the Central Government defined the area around the LLNP as the buffer zone aiming to protect the core area. Overall 118 villages comprising approximately 130,000 inhabitants are located in LLBR (Faust et al. 2003). This corresponds to a population density of 18.69 inhabitants per $\mathrm{km}^{2}$ (Faust et al. 2003). A total of 64 of the villages are situated in direct proximity to the core area whereas the border to the transition area is not yet specified (Widagdo 2008). 
Table 1. Management plan draft for Lore Lindu Biosphere Reserve.

\begin{tabular}{|c|c|}
\hline Zone & Management effort \\
\hline Core area & $\begin{array}{l}\text { Goal: Conservation of biodiversity } \\
\text { - Involvement of local people (collaborative } \\
\text { monitoring of flora and fauna) } \\
\text { - Development of ecotourism (bird watching, guided } \\
\text { tours to hot springs and Megalith) } \\
\text { - (international) research cooperation (NGOs, } \\
\text { universities) }\end{array}$ \\
\hline
\end{tabular}

Buffer Goal: Guarantee protection of core area through zone sustainable use of natural resources - Implementation of sustainable development activities (honey production, cattle breeding) - Implementation of collaborative management strategies (introducing Community Conservation Agreements between local people and park authority)

Transition Goal: Implementation of successfully tested area sustainable development approaches - Collaboration with researchers, local communities, and other stakeholders

Source: Widagdo (2008)

The region is extremely important from an environmental conservation point of view because of its unique biodiversity. Located to the east of Wallace's line it is internationally recognized as a Global 200 Ecoregion (Widagdo 2008). The area is considered an outstanding representative of the world's terrestrial ecosystems due to its species richness, endemism, high taxonomic uniqueness, and keystone habitats (Widagdo 2008). Besides this ecological uniqueness there is also an astonishing cultural heritage of ancient stone megaliths from 1300 AD. Several distinct ethnic groups are living in the villages adopting traditional customary laws (Widagdo 2008). The region is predominantly a rural area and the majority of the households depend on agriculture as the primary source of income (Maertens et al. 2006). The principal food crop is paddy rice, while cacao and coffee are important cash crops (Maertens et al. 2006). Agricultural expansion, particularly for cacao production, threatens the integrity of the core area as the land used for farming is increasing (Faust et al. 2003).

\section{Satellite image analysis}

A time series of LANDSAT scenes from 1972, 1983, 1999, 2002, and 2007 was used to classify homogeneous areas of forest cover to detect deforestation. According to Lund (1999), deforestation is defined as the long-term or permanent removal of forest cover and conversion to non-forested land. Reforestation, afforestation, and regrowth were not considered for this analysis. The classification procedure was carried out by our cooperation partner STORMA (Stability of Rainforest Margins in Indonesia), University of Göttingen, Germany (see Erasmi et al. 2004). The whole process includes the following steps: (1) Creation of a cloud mask using reflectance thresholds for the red and mid-infrared image channels for each data set respectively, (2) Segmentation of the imagery based on spectral and spatial attributes of the data set such as height, inclination, and historical land use, (3) Definition of object classes such as natural forest, open forest, perennial crops, annual crops, grassland, water, and built-up areas, and installation of 65 ground control points, (4) Fuzzy logic classification of segmented images, and (5) Accuracy assessment with an average membership probability of 0.93 (1972) and 0.87 (2002), (Erasmi et al. 2004). For a detailed explanation, please see Erasmi et al. (2004). These classified data were matched in a GIS and aggregated in a $30 \times 30$ meter grid. Subsequently change analysis was carried out. Areas of forest and non-forest were calculated for each point in time. Furthermore, the deforestation rate was computed for the periods before and after management establishment in 1998. Thus, the difference in forest cover between the images from 1972 and 1983 (before management establishment) as well as the difference between 1999 and 2007 (after management establishment) were calculated.

The calculation of forest cover and deforestation rate was performed for the total area, core area, and buffer zone. For satellite image analysis the total area is defined as the five subdistricts covering an area of approximately 7,500 square kilometers. The core area corresponds to the area of LLNP comprising 2,200 square kilometers (Erasmi et al. 2004). To include the villages in direct proximity to the core area, we defined the buffer zone as a three kilometer buffer around the core area, including the two enclaves located inside LLNP. This buffer zone covers an area of some 1,100 square kilometers and includes 67 villages.

\section{Interview process and analysis}

A systematic qualitative social research approach was applied that included in-depth interviews and group discussions (Punch 2005). These interviews and discussions provided us with important insights into the local institutional dimensions and their interaction within the context of BR management including, for example, legal backing and responsibilities for the buffer zone or collaboration with the local people.

Data collection was carried out between March and May 2008. Applying a preferential sampling design, the selection of participants for the interviews was done through snowball sampling (Punch 2005). This involved the initial identification 
Table 2. Overview of interviews and group discussions in Lore Lindu Biosphere Reserve (LLBR).

\begin{tabular}{|c|c|c|}
\hline Level & Social entity & Interview partner \\
\hline Local & $\begin{array}{l}\text { Villagers } \\
\text { Local authorities } \\
\text { NGOs }\end{array}$ & $\begin{array}{l}\text { Farmers (men and women) in } 4 \text { different villages in the buffer zone: Tuwa, Tomado, Wuasa, } \\
\text { Katu } \\
\text { Mayor, sub-district administrator } \\
\text { TNC } \\
\text { The Nature Conservancy; international NGO, focus on nature conservation }\end{array}$ \\
\hline & LLBR staff & $\begin{array}{l}\text { YTM } \\
\text { Yayasan Tanah Merdeka ("Independent Earth Foundation"); national NGO, focus on human } \\
\text { rights } \\
\text { KARSA } \\
\text { "initiate"; national NGO, focus on nature conservation } \\
\text { Jambata } \\
\text { "bridge"; national NGO, focus on nature conservation } \\
\text { Former and current head, forest police, staff members }\end{array}$ \\
\hline Sub-national & $\begin{array}{l}\text { Local government } \\
\text { authorities }\end{array}$ & $\begin{array}{l}\text { Nature conservation agency } \\
\text { (BKSDA: Balai Konservasi Sumber Daya Alam) } \\
\text { Agency for planning and development } \\
\text { (BAPPEDA: Badan Perencana Pembangunan Daerah) } \\
\text { Water catchment agency } \\
\text { (BPDAS: Badan Pengelolaan Daerah Aliran Sungai) } \\
\text { Forest observation agency } \\
\text { (BPKH: Balai Pemantapan Kawasan Hutan) }\end{array}$ \\
\hline National & MAB committee & MAB head and committee members \\
\hline
\end{tabular}

of individuals and interviewing of key people such as both the recent and the former head of LLBR. These initial interviewees then guided the research team to further contacts. Following this approach, respondents representing the local, subnational, and national level associated with the LLBR management were interviewed (Table 2). Criteria for the saturation of information were derived from the concept of theoretical sampling (Flick 1995). This concept is related to the question of what empirical data are needed to advance the understanding of the investigated aspect (Glaser and Strauss 1967). Data collection is complete when the addition of new interviewees provides no additional relevant information for a comprehensive understanding of the issue (Flick 1995). Besides these interviews, group discussions were carried out to interview farmers living in the buffer zone (Table 2). Four contrasting villages were chosen, which varied in terms of the sustainable development activities being undertaken by NGOs and the location of the villages within the buffer zone (Figure 1). For a detailed explanation of the village selection criteria, please see Mehring and Stoll-Kleemann (2010).
Overall, findings from 25 interviews and group discussions were integrated. The interviews and discussions focused on implementation, zonation, and perception of the LLBR and its management. Questions and interview guidelines differed between villagers, MAB committee members, and other interviewees (see Appendix 2). Interviews were conducted with the help of local assistants in the national language Bahasa Indonesia and fully recorded. Subsequently, the interviews were transcribed and translated into English by local assistants. According to the content analysis approach (Punch 2005), computer-based analysis with ATLAS.ti was carried out. A two-step analysis of open and axial coding drawn from Grounded Theory Analysis (Glaser and Strauss 1967) was applied. Open coding includes raw data reduction into categories. For an overview of the codes used for our analysis, please see Appendix 3. Axial coding was applied using a coding paradigm to identify causal relationships between identified categories (Glaser and Strauss 1967). 
Fig. 2. Area of forest and non-forest cover in Lore Lindu Biosphere Reserve in 1972 and 2007. Data source: Stability of Rainforest Margins Project (STORMA), University of Göttingen, Germany; own illustration.

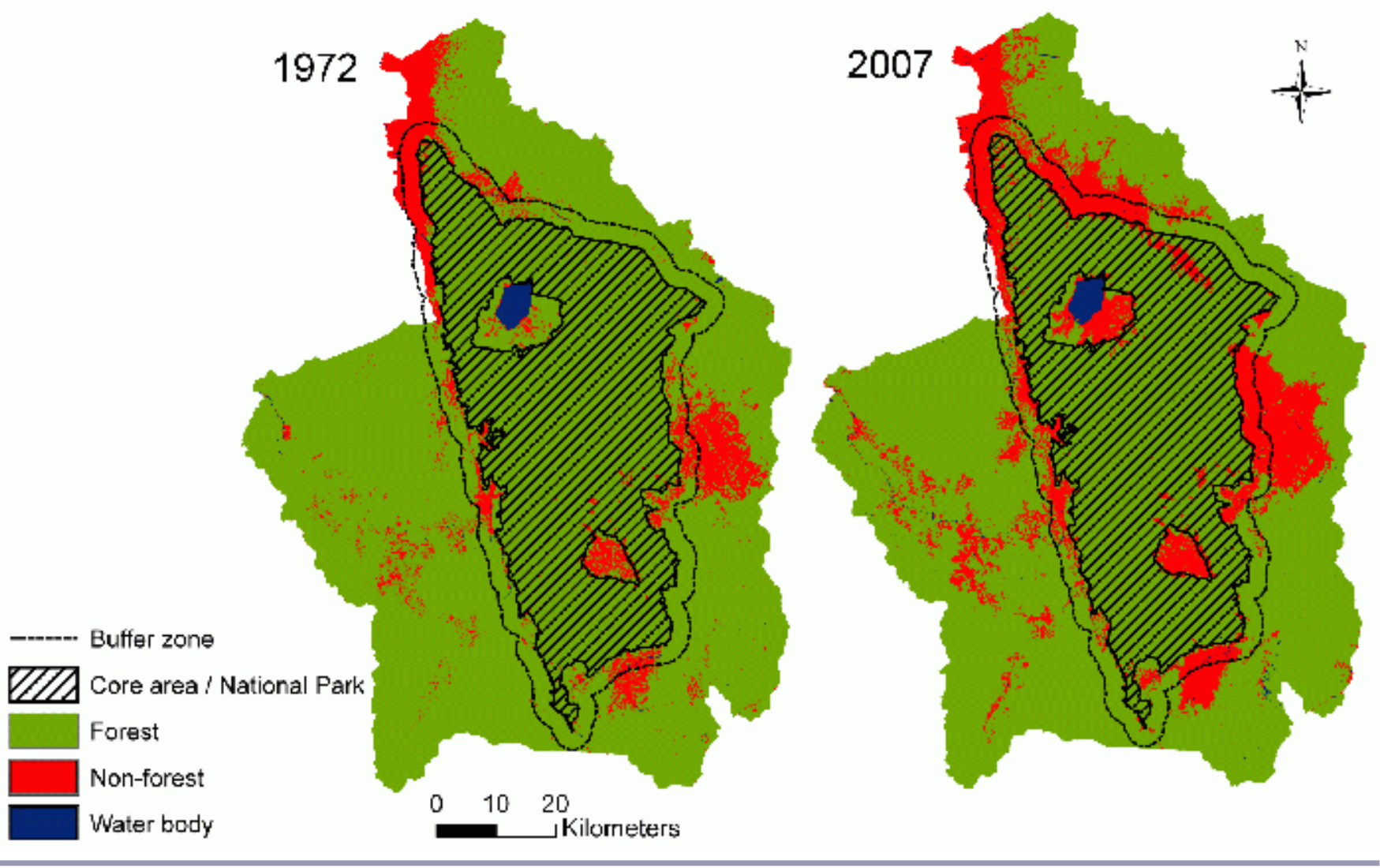

\section{RESULTS}

\section{Satellite images}

Time-series analyses of remotely sensed images enabled us to identify trajectories of forest cover change. Figure 2 shows how forest cover has changed over time. In Figures 3 and 4 we present the forest cover results, as well as deforestation rates before and after management establishment, respectively.

Our results show that forest cover in LLBR is decreasing over time. The core area exhibits the highest forest cover, with over $95 \%$ perennial cover but is still subject to deforestation. In contrast, the buffer zone had already experienced significant deforestation by 1972 with $74 \%$ forest cover and was subject to the highest further loss of forest compared to the core area and transitional area.

The calculation of deforestation rates before and after the establishment of the management body reveals no differences for the total area $(0.23 \%$ per year). However, there are clear differences between the core area and the buffer zone. In the latter, the deforestation rate decreased from 0.79 to $0.68 \%$ per year after management establishment, although overall it still remained high. However, in the core area, the deforestation rate increased from 0.06 to $0.27 \%$ per year after 1998 , thereby exceeding the value for the total area. However, there are spatial variations in deforestation activities in both the core area and the buffer zone. Most of the deforestation in the core area occurred in the northeastern part where the road connecting Dongala and Poso regencies crosses the core area (Figures 2 and 3). Figure 2 further highlights that the northern and eastern part as well as both enclaves experienced the highest levels of deforestation in the buffer zone. Overall, this corresponds to a forest loss of 520 square kilometers for the total area, 74 square kilometers for the core area, and 220 square kilometers for the buffer zone between 1972 and 2007.

\section{Interviews}

Figure 5 shows the main institutional drivers as a collation of different insights from different groups of stakeholders and their positive and negative interaction on buffer zone management in LLBR. When considered appropriate, direct quotations are given. The quotation number assigned by ATLAS.ti is indicated and the group affiliation of the interview 
Fig. 3. Forest cover (\%) in Lore Lindu Biosphere Reserve between 1972 and 2007. Data source: Stability of Rainforest Margins Project (STORMA), University of Göttingen, Germany; own illustration.

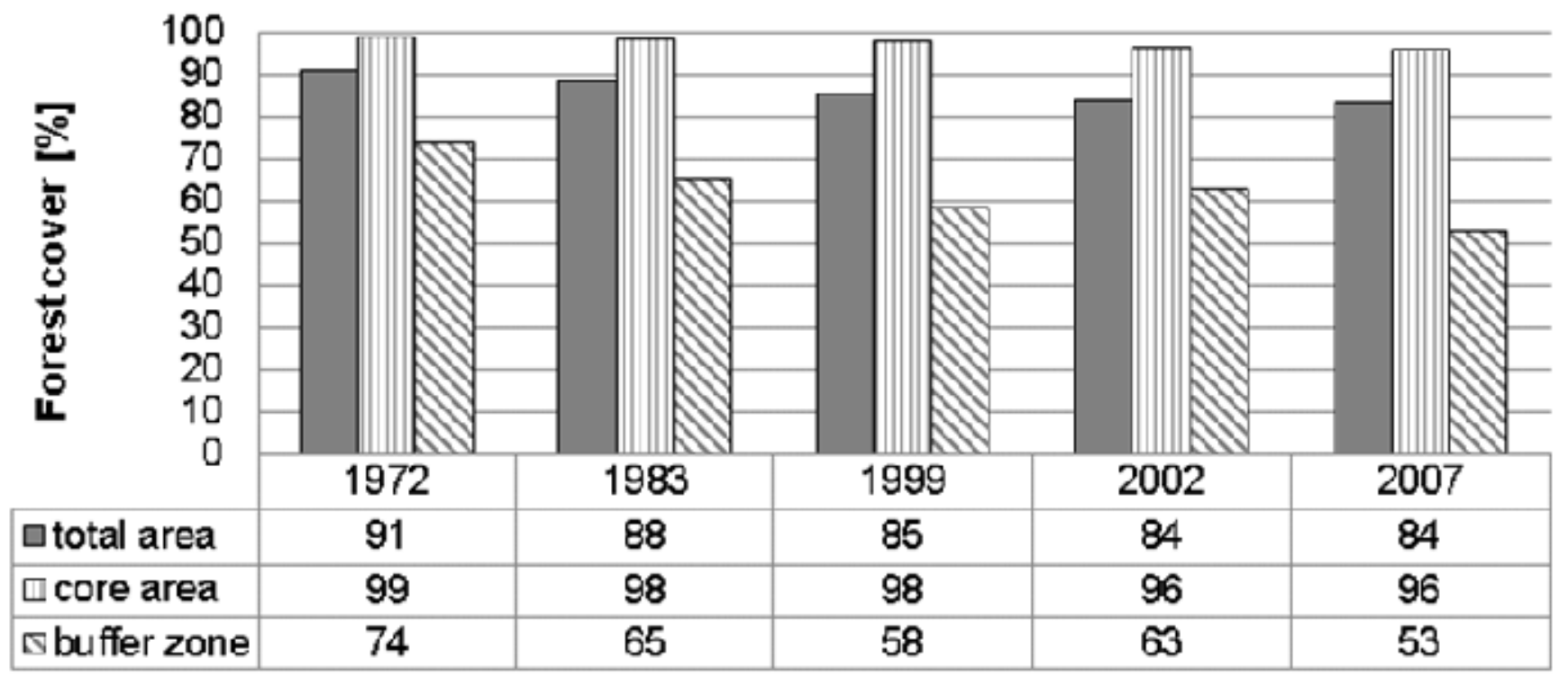

partner is shown.

Fig. 4. Deforestation rate (\%/year) in Lore Lindu Biosphere Reserve before and after establishing management body.

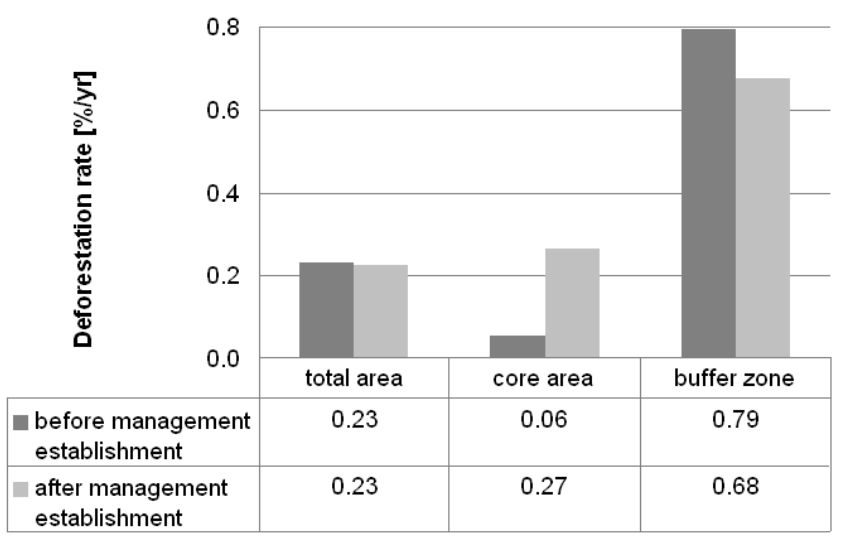

A differentiation between forest and management valuation was observed among all farmers interviewed. This difference appeared in a positive valuation of the forest and its functions, such as protection against floods and erosion. Due to personal experience, such as with recent flood disasters, the inhabitants had learned to appreciate the protective value of the forest and the importance of saving it (20:6; farmer). Although this ecological understanding among the farmers was observed, the fact that the responsibility for managing and conserving the forest has been assumed by the NP administration rather than by the people themselves was perceived as negative and unnecessary. As one interview partner stated: "Almost all people [inhabitants] say that there is no need for LLNP" (11:10; NGO). The way the LLNP and its boundary were established and are being managed was highlighted as the main reason for this negative perception. In the establishment of the boundary between the core area and the buffer zone the local people were not consulted or engaged. At that time the government considered participation to mean participation of the district head. Since the fall of Suharto as president in 1998, local people have acquired more power and now complain about the lack of participation in this process $(5: 21$; NGO). The inhabitants feel excluded and don't understand the zonation promoted by LLNP authority (24:2; local authority) as it contradicts the local traditional system for the use and management of the forest (11:3; NGO). One interview partner even claimed that "without LLNP the forest could be saved" (24:2; local authority). Another interviewee explained "that the concept of the biosphere reserve with its zonation is a concept of Jakarta. [...] The inhabitants have developed their own definition [...] and the word 'biosphere reserve' doesn't exist in their mind" (14:9; NGO).

UNESCO came up with the idea of joining the World Network of Biosphere Reserves (WNBR) (8:4; local government authority). In the early 1970s UNESCO together with the Indonesian Forestry Department decided to establish six BRs representing different types of ecosystems in Indonesia (3:6; MAB committee). Subsequently the Ministry of Forestry 
Fig. 5. Institutional drivers at national, sub-national, and local level impacting buffer zone management in Lore Lindu Biosphere Reserve. Red arrows indicate negative influence and green arrows depict positive consequences.

Positive Negative

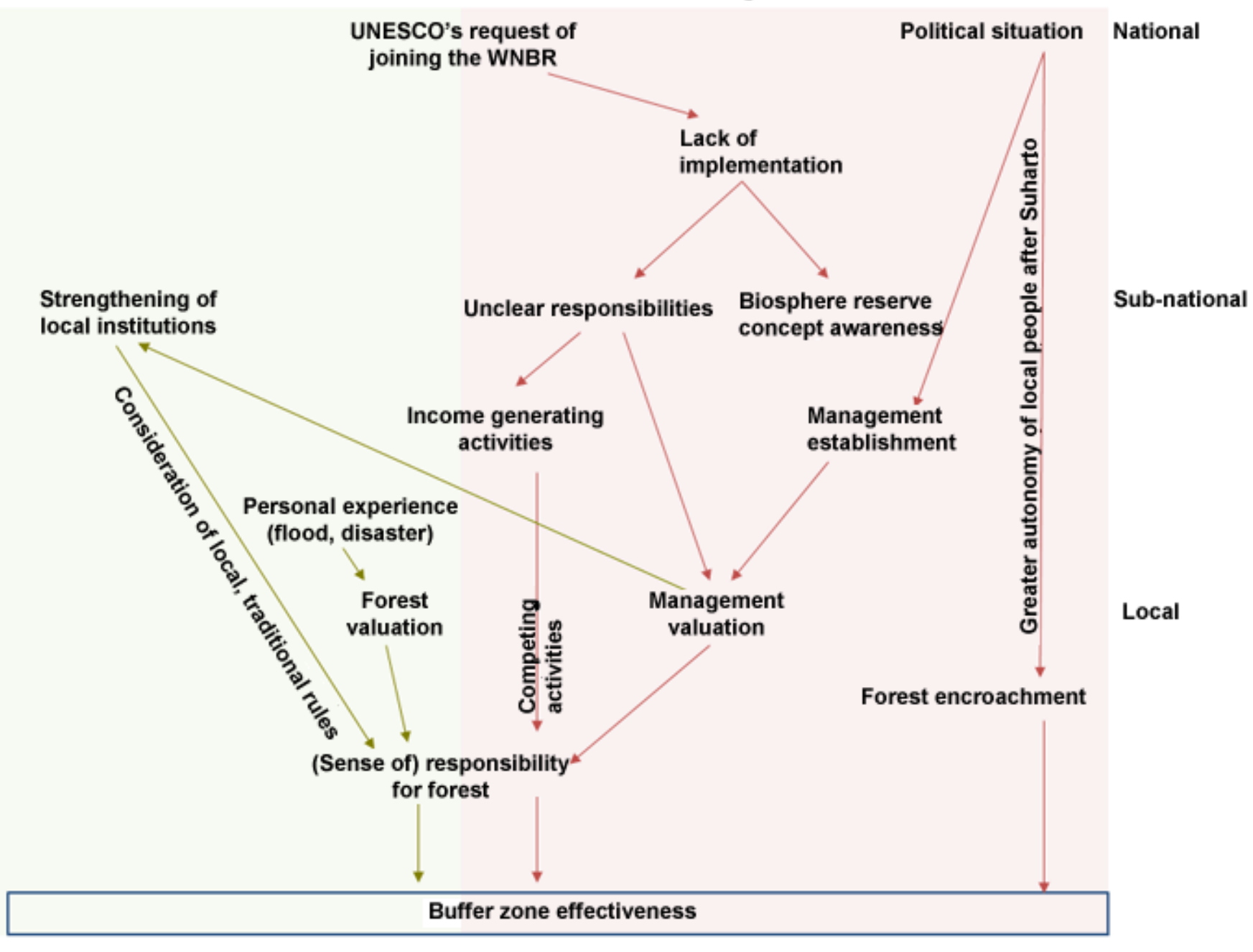

handed over the responsibility to the Indonesian Institute of Sciences (Lembaga Ilmu Pengetahuan Indonesia: LIPI) (1:9; MAB committee). Thus far, the BR concept, including adoption of clearly defined regulations, has not been implemented at the national level (1:8; MAB committee). Besides ignorance of the BR concept at the sub-national level, this lack of implementation leads to unclear responsibilities among government agencies. The LLNP authority says that the buffer zone is not their job, rather it is the responsibility of the local government (10:12; LLBR staff). In contrast, employees of the local government raise the criticism that to date there is no rule regulating buffer zone responsibility $(7: 12$; local government authority). However, both local government and LLBR authority are aware of forest encroachment associated with the lack of consideration of local people's needs. Thus, they have both separately started income generating activities in the buffer zone, such as honey production, handicrafts, and cattle breeding. These wellintentioned activities have not been successful nor accepted by the local people, especially when carried out alongside each other in the same village (16:5; local government authority).

Besides income generating activities, the LLBR authority has started to integrate local traditional rules in their management. During the last decade, community conservation agreements (CCAs) among LLBR, NGOs, and inhabitants have been negotiated. The CCA rules are seen to be more powerful and are more respected by the people than the national rules enforced by the LLBR (5:29; NGO). 


\section{DISCUSSION}

Satellite image analysis shows that forest cover in the core area has decreased since the establishment of the management body, indicating the park's ineffectiveness at reducing deforestation. This result deviates from findings by Bruner et al. (2001). Based on expert interviews in 93 PAs in 22 tropical countries, they calculated that only a minority of the parks included in the study (17\%) experienced forest loss within the boundary since establishment. However, our results are more consistent with other studies based on satellite image analysis (e.g., Curran et al. 2004, DeFries et al. 2005, Naughton-Treves et al. 2005, Nagendra 2008). In these studies the investigators still found deforestation within the park boundary. In LLBR the deforestation rate in the core area increased from $0.06 \%$ to $0.27 \%$ per year after management establishment while a simultaneous decrease was observed in the buffer zone. If the latter remains valid, the reasons for it needs to be explored. The decrease in the buffer zone might be due to seasonal variations during satellite image recording rather than to local drivers. There are in fact considerable spatial variations of water bodies in the buffer zone between the dry and rainy seasons. However, this does not apply to the core zone and we thus conclude that the satellite image analysis indicates that the buffer zone in LLBR was not effective at protecting the core area against encroachment.

Worldwide, forest cover is decreasing in several countries with still alarmingly high rates (FAO 2010) and Indonesia is no exception. Thus, the question arises as to whether LLBR counteracted the country-wide trend, even though we detected deforestation within the core area. Interview analysis allowed us to interpret the satellite information on forest cover change. The inhabitants perceive the forest positively and acknowledge the importance of keeping it. According to our interview partners, this is ascribed to personal learning processes rather than to management outreach. Instead, LLNP and its management are viewed negatively and the need for their existence is questioned. This is in line with Sodhi et al. (2010) who conclude from studies in four developing Southeast Asian countries that local people recognize the importance of environmental services, including cultural, provisioning, and regulating services, provided by forested parks, although conflicts between park management and inhabitants exist. The study from Berghoefer et al. (2010) has illustrated how different "natures" are created in the relationship among individuals, society, and the physical world. They conclude that the typical dichotomy between use and protection in terms of natural resource use has little explanatory relevance and they claim that a differentiated view of local awareness concerning natural resources needs to be applied. In the case of LLBR, local people clearly differentiate between the resource and the institutional setting. Elmqvist et al. (2007) also highlight that forest cover change cannot be understood as an ecological process alone; rather, it is embedded in an institutional context depending on local rules. On the one hand villagers in LLBR appreciate the protection value of the forest and on the other hand they see no need for an external authority to manage the forest, because they feel themselves responsible for the forest. The local people feel rather ignored because local traditional forest use and management systems were not taken into consideration during the establishment of the management regime. These findings provide evidence that the management in LLBR does not seem to be counteracting the deforestation trend.

Instead, there is strong evidence from satellite image and interview analysis that the management establishment has further spurred deforestation. During interviews, the way the park was established and is being managed were highlighted as the main reasons for resistance to the park and its boundary. In 1998, the permanent borders of the core area were established without participation of the local people and the management body was established by the national Ministry of Forestry. After management establishment and boundary demarcation, the deforestation rate in the core area increased fourfold. Several studies have already proven that government-imposed PAs without participation of local people have generated substantial conflicts between local people and park authorities resulting in resistance to the park (Dudley and Stolton 1999, Agrawal and Ostrom 2001, Dietz et al. 2003, WWF 2004, Nagendra et al. 2005). However, considering the national political context of Indonesia, there are broader issues at play. Boundary demarcation and management establishment coincided with the fall of President Suharto in 1998. From studies on Sumatra and Indonesian Borneo we know that after the fall of the national president and subsequent decentralization efforts deforestation within PAs increased dramatically (Curran et al. 2004, Gaveau et al. 2009). In LLBR massive deforestation in the northeastern part of the core area occurred after 1998 along the road passing through the core area. These illegal logging activities can directly be related to the national political change at the time (Adiwibowo 2005). This so called "Dongi-dongi" conflict, where settlers occupied and deforested the area, implies that people sought to reclaim a balance in the dominationrepression power imbalance (Adiwibowo 2005). This is also in line with Mehring et al. (2011) who point to significant forest exploitation within the core area of LLBR after the political change. However, overall deforestation in the LLBR cannot solely be explained by this phenomenon. Forest clearing in the buffer zone and to a minor extent in other parts of the core area is also due to additional local drivers of change. The highest amount of clearing in the buffer zone spatially cooccurs with the areas of highest population density and favorable land conditions for agriculture. The northern subdistricts Sigi Biromaru and Palolo have both attributes with high population density values of 86.49 and 42.96 inhabitants per $\mathrm{km}^{2}$ respectively, and a flat topography (Faust et al. 2003). 
The eastern part (Lore Utara) is characterized by flat topography whereas the western part (Kulawi) constitutes a narrow and sparsely populated valley. These logging activities are being carried out for subsistence purposes rather than commercial ones (Maertens et al. 2006).

In the case of LLBR, the local government as well as the LLBR authority are aware of the conservation needs to protect the core area against encroachment. Both agencies attribute deforestation in the core area to a lack of consideration of local people's needs in the past. But as long as the BR concept is not being implemented at the national level, the legal backing to integrate the inhabitants is not clear. At this point, nobody is legally responsible for carrying out such cooperation activities in the buffer zone, but both agencies get money from the Ministry of Forestry to conduct activities, such as alternative income generation. Similar to the way of management establishment, these activities are not being carried out in cooperation with the local people nor do they acknowledge traditional use rights before management establishment. Moreover, sustainable forest use is not yet addressed by any of the authorities. Thus, the local people's sense of responsibility for the forest is not restored, resulting in rejection of these income generating activities. Recent studies on sustainable resource use suggest that integrating local people can be very effective, based on the argument that resources are better conserved when the people can use them and therefore value them as part of their livelihood (Brandon et al. 1998, Ostrom et al. 1999, Bates and Rudel 2000, Ostrom and Nagendra 2006).

Although we found accelerated deforestation after management establishment within the core area, it has to be highlighted that forest cover in LLBR is still high compared to other islands in Indonesia. Large-scale deforestation at a rate of $9.5 \%$ per year, as observed within a PA in Borneo (Curran et al. 2004) does not occur in LLBR. Rather, the deforestation rates in the total area and the core area in LLBR are of the same order of magnitude as worldwide deforestation, with some $0.2 \%$ deforestation per year (FAO 2007) and are beneath the average forest loss calculated for Indonesia between 2000 and 2010 of $0.51 \%$ per year (FAO 2010). The LLBR authority is well aware of the conflict between people and the park in recent years and has started carrying out initiatives to address this issue. Elements of collaborative management are being implemented. For this reason, community conservation agreements (CCAs) between local people and LLBR were negotiated on a village level since the late 1990s. National and international NGOs mediated these processes. These CCAs integrate local, traditional rules concerning forest use and punishment in case of rule violation. Long-term studies from Ostrom and Nagendra (2006) show that when local people are genuinely engaged in decisions regarding rules that affect their use of natural resources, the likelihood of users following the rules is much greater than when an authority simply imposes such rules. By considering local traditional rules on forest use and sanctioning in LLBR, the people's responsibility for the forest has been restored. Thus, CCAs show great potential to have a positive impact on management effectiveness. However, whether the CCAs are able to live up to this promise remains to be seen. Critical concerns regarding discrimination against groups of villagers such as migrants, for example, have already been expressed (Mappatoba and Birner 2004, Mehring et al. 2011).

\section{CONCLUSION}

Overall, satellite image analysis shows that the buffer zone in LLBR was not effective at reducing deforestation in the core area. From our interview analysis we identify three main institutional drivers hindering effective buffer zone management in LLBR: (1) Low awareness of boundary demarcation among the villagers due to lack of participation during management and boundary establishment, (2) The fall of the national president Suharto, which subsequently triggered deforestation activities in the core area as the park was perceived to be the local branch of the national, suppressive regime of Suharto, (3) The fact that the buffer zone responsibility has not yet been clarified among local government agencies due to the lack of implementation of the biosphere reserve concept and its regulatory system at the national level.

Our investigation in LLBR is an illustrative example of how different institutional factors at different levels (national, subnational, local) influenced management on the ground and negatively impacted buffer zone effectiveness. In this sense an integrated research approach combining satellite image analysis and social science field research is needed because without techniques, such as remote sensing, to assess the effectiveness on the ground, no statement about the effectiveness in maintaining forest cover can be made and without social field research, no conclusion can be drawn about the drivers of success or failure.

To address the identified factors, different steps need to be taken in LLBR. First of all we recommend to the MAB committee that the biosphere reserve concept be implemented at the national level with its regulatory system concerning zonation and participation. This implementation is a precondition for regulating and coordinating any buffer zone activity and responsibility. Thus, human resources and economic resources could be saved and more efficiently used when combining the activities undertaken by the local government and LLBR, rather than each working separately alongside each other.

On the local BR level, we recommend a focus on both income generating activities and confidence-building among inhabitants concerning the management body. LLBR should take advantage of the positive relation of learning and understanding through personal experience among the 
inhabitants. Focusing on environmental education activities, these activities could serve to strengthen the BR's role as a "learning laboratory" and could also raise local peoples' awareness of the role of the management body. Income generating activities are especially required in those areas of the buffer zone where the population density is highest and resource access is limited. However, previous efforts have not been successful so far and have not genuinely addressed local peoples' needs to use the forest instead of being excluded. Income generating activities should be carried out in a coordinated manner with both authorities working together. The success of these activities is also important for similar endeavors such as implementing Reducing Emissions from Deforestation and Degradation (REDD) in Indonesia to counteract deforestation.

Responses to this article can be read online at: http://www.ecologyandsociety.org/voll6/iss4/art3/responses/

\section{Acknowledgments:}

We thank the Robert Bosch foundation for funding the GoBi (Governance of Biodiversity) research project and our cooperation partner STORMA for providing satellite images. The present study was financially supported by the research funding program "LOEWE-Landes-Offensive zur Entwicklung Wissenschaftlich-ökonomischer Exzellenz" of Hesse's Ministry of Higher Education, Research, and the Arts. We further thank Nele Leiner for satellite image analysis. Special thanks go to local assistants in Indonesia for field assistance, transcription, and translation, and to all interviewees.

\section{LITERATURE CITED}

Adiwibowo, S. 2005. Dongi-dongi - culmination of a multidimensional ecological crisis: a political ecology perspective. Inaugural dissertation, University of Göttingen, Germany.

Agrawal, A., and E. Ostrom. 2001. Collective action, property rights, and decentralization in resource use in India and Nepal. Politics and Society 29:485-514. http://dx.doi.org/10.1177/00 $\underline{32329201029004002}$

Andam, K. S., P. J. Ferraro, A. Pfaff, G. A. Sanchez-Azofeifa, and J. A. Robalino. 2008. Measuring the effectiveness of protected area networks in reducing deforestation. Proceedings of the National Academy of Sciences of the United States of America 105:16089-16094. http://dx.doi.org/10.1073/ pnas.0800437105

Bates, D., and T. K. Rudel. 2000. The political ecology of conserving tropical rain forests: a cross-national analysis. Society \& Natural Resources 13:619-634. http://dx.doi.org/10 $.1080 / 08941920050121909$
Batisse, M. 1993. Biosphere reserves: an overview. Nature and Resources 29:1-4.

Berghoefer, U., R. Rozzi, and K. Jax. 2010. Many eyes on nature: diverse perspectives in the Cape Horn Biosphere Reserve and their relevance for conservation. Ecology and Society 15(1):18. [online] URL: http://www.ecologyandsociety. org/vol15/iss1/art18/

Brandon, K., K. Redford, and S. Sanderson. 1998. Parks in peril: people, politics and protected areas. Island Press, Washington D.C., USA.

Bruner, A. G., R. E. Gullison, R. E. Rice, and G. A. B. da Fonseca. 2001. Effectiveness of parks in protecting tropical biodiversity. Science 291:125-128. http://dx.doi.org/10.1126/ science.291.5501.125

Chape, S., J. Harrison, M. Spalding, and I. Lysenko. 2005. Measuring the extent and effectiveness of protected areas as an indicator for meeting global biodiversity targets. Philosophical Transactions of the Royal Society B:Biological Sciences 360:443-455. http://dx.doi.org/10.1098/rstb.2004.1592

Curran, L. M., S. N. Trigg, A. K. McDonald, D. Astiani, Y. M. Hardiono, P. Siregar, I. Caniago, and E. Kasischke. 2004. Lowland forest loss in protected areas of Indonesian Borneo. Science 303:1000-1001. http://dx.doi.org/10.1126/science.10 $\underline{91714}$

DeFries, R. S., A. Hansen, A. C. Newton, and M. C. Hansen. 2005. Increasing isolation of protected areas in tropical forests over the past twenty years. Ecological Applications 15:19-26. http://dx.doi.org/10.1890/03-5258

Dietz, T., E. Ostrom, and P. C. Stern. 2003. The struggle to govern the commons. Science 302:1907-1912. http://dx.doi.o $\mathrm{rg} / 10.1126 /$ science. 1091015

Dudley, N., and S. Stolton. 1999. Threats to forest protected areas. IUCN, Gland, Switzerland.

Elmqvist, T., M. Pyykonen, M. Tengo, F. Rakotondrasoa, E. Rabakonandrianina, and C. Radimilahy. 2007. Patterns of loss and regeneration of tropical dry forest in Madagascar: the social institutional context. PLoS ONE 2(5). http://dx.doi.org /10.1371/journal.pone.0000402

Erasmi, S., A. Twele, M. Ardiansyah, A. Malik, and M. Kappas. 2004. Mapping deforestation and land cover conversion at the rainforest margin in Central Sulawesi, Indonesia. EARSeL eProceedings. 3(3):388-397. [online] URL: http://las.physik.uni-oldenburg.de/eProceedings/ vol03 3/03 3 erasmil.pdf

FAO. 2007. State of the world's forests. Food and Agriculture Organization of the United Nations, Rome, Italy. 
FAO. 2010. Global forest resources assessment 2010 - main report. Food and Agriculture Organization of the United Nations, Rome, Italy.

Faust, H., M. Maertens, R. Weber, N. Nuryartono, T. van Rheenen, and R. Birner. 2003. Does migration lead to destabilization of forest margins? - evidence from an interdisciplinary field study in Central Sulawesi. Discussion Paper Series, No. 11. Research Project on Stability of Rain Forest Margins (STORMA), Göttingen, Germany.

Flick, U. 1995. Qualitative forschung. Rowohlt, Reinbek, Germany.

Folke, C., L. Pritchard, Jr., F. Berkes, J. Colding, and U. Svedin. 2007. The problem of fit between ecosystems and institutions: ten years later. Ecology and Society 12(1):30. [online] URL: http://www.ecologyandsociety.org/vol12/iss1/ $\underline{\operatorname{art} 30 /}$

Gaveau, D. L. A., M. Linkie, S. Suyadi, P. Levang, and N. Leader-Williams. 2009. Three decades of deforestation in southwest Sumatra: effects of coffee prices, law enforcement and rural poverty. Biological Conservation 142:597-605. htt p://dx.doi.org/10.1016/j.biocon.2008.11.024

Glaser, B. G., and A. Strauss. 1967. Discovery of grounded theory. Strategies for qualitative research. Sociology, Mill Valley, USA.

Guevara, S., and J. Laborde 2007. The landscape approach: designing new reserves for protection of biological and cultural diversity in Latin America. Environmental Ethics 30:251-262.

Hockings, M. 2003. Systems for assessing the effectiveness of management in protected areas. BioScience 53:823-832.

Hummel, D., T. Jahn, E. Schramm. 2011. Social-ecological analysis of climate induced changes in biodiversity- outline of a research concept. BiK-F Knowledge Flow Paper No. 11, Frankfurt am Main, Germany. [online] URL: http://www.bikf.de/files/publications/kfp nr-11 neu 71c3b9.pdf

Ishwaran, N., A. Persic, and N. H. Tri. 2008. Concept and practice: the case of UNESCO biosphere reserves. International Journal of Environment and Sustainable Development 7:118-131. http://dx.doi.org/10.1504/IJESD.20 $\underline{08.018358}$

Joppa, L. N., S. R. Loarie, and S. L. Pimm. 2008. On the protection of "protected areas". Proceedings of the National Academy of Sciences of the United States of America 105:6673-6678. http://dx.doi.org/10.1073/pnas.0802471105

Linkie, M., R. J. Smith, Y. Zhu, D. J. Martyr, B. Suedmeyer, J. Pramono, and N. Leader-Williams. 2008. Evaluating biodiversity conservation around a large Sumatran protected area. Conservation Biology 22:683-690. http://dx.doi.org/10. 1111/j.1523-1739.2008.00906.x

Lund, G. 1999. A 'forest' by any other name. Environmental Science and Policy 2:125-134. http://dx.doi.org/10.1016/S14 $\underline{62-9011(98) 00046-X}$

Maertens, M., M. Zeller, and R. Birner. 2006. Sustainable agricultural intensification in forest frontier areas. Agricultural Economics 34:197-206. http://dx.doi.org/10.1111/ j.1574-0864.2006.00118.x

Mappatoba, M., and R. Birner. 2004. Co-management of protected areas: the case of community agreements on conservation in the Lore Lindu National Park, Central Sulawesi, Indonesia. Deutsche Gesellschaft für Technische Zusammenarbeit (GTZ) GmbH, Eschborn, Germany.

Mehring, M., C. Seeberg-Elverfeldt, S. Koch, J. Barkmann, S. Schwarze, and S. Stoll-Kleemann. 2011. Local institutions: regulation and valuation of forest use - evidence from Central Sulawesi, Indonesia. Land Use Policy 28:736-747. http://dx.d oi.org/10.1016/j.landusepol.2011.01.001

Mehring, M., and S. Stoll-Kleemann. 2010. Principle and practice of the buffer zone in biosphere reserves: from global to local - general perspective from managers versus local perspective from villagers in Central Sulawesi, Indonesia. Pages 413-429 in T. Tscharntke, C. Leuschner, E. Veldkamp, H. Faust, E. Guhardja, and A. Bidin, editors. Tropical rainforests and agroforests under global change. Springer Verlag, Heidelberg, Germany. http://dx.doi.org/10.1007/9783-642-00493-3_19

Nagendra, H. 2008. Do parks work? Impact of protected areas on land cover clearing. AMBIO: A Journal of the Human Environment 37:330-337. http://dx.doi.org/10.1579/06-R-184.1

Nagendra, H., M. Karmacharya, and B. Karna. 2005. Evaluating forest management in Nepal: views across space and time. Ecology and Society 10(1):24. [online] URL: http:/ /www.ecologyandsociety.org/vol10/iss1/art24/

Naughton-Treves, L., M. B. Holland, and K. Brandon. 2005. The role of protected areas in conserving biodiversity and sustaining local livelihoods. Annual Review of Environment and Resources 30:219-252. http://dx.doi.org/10.1146/annurev. energy.30.050504.164507

Neumann, R. P. 1997. Primitive ideas: protected area buffer zones and the politics of land in Africa. Development and Change 28:559-582. http://dx.doi.org/10.1111/1467-7660.00054

Ostrom, E., J. Burger, C. B. Field, R. B. Norgaard, and D. Policansky. 1999. Revisiting the commons: local lessons, global challenges. Science 284:278-282. http://dx.doi.org/10. $\underline{1126 / \text { science. } 284.5412 .278}$ 
Ostrom, E., and H. Nagendra. 2006. Insights on linking forests, trees, and people from the air, on the ground, and in the laboratory. Proceedings of the National Academy of Sciences of the United States of America 103:19224-19231. http://dx.d oi.org/10.1073/pnas.0607962103

Punch, K. F. 2005. Introduction to social research: quantitative and qualitative approaches. Second edition. Sage, London, UK.

Schonewald-Cox, C. M., M. Buechner, R. Sauvajot, and B. A. Wilcox. 1992. Cross-boundary management between national parks and surrounding lands: a review and discussion. Environmental Management 16:273-282. http://dx.doi.org/10 $.1007 / \mathrm{BF} 02393833$

Shohibuddin, M. 2008. Discursive strategies and local power in the politics of natural resource management: the case of Toro village. Pages 91-132 in G. Burkard, and M. Fremerey, editors. A matter of mutual survival. Lit Verlag Dr. W. Hopf, Berlin, Germany.

Sodhi, N. S., T. M. Lee, C. H. Sekercioglu, E. L. Webb, D. M. Prawiradilaga, D. J. Lohman, N. E. Pierce, A. C. Diesmos, M. Rao, and P. R. Ehrlich. 2010. Local people value environmental services provided by forested parks. Biodiversity and Conservation 19:1175-1188. http://dx.doi.or $\mathrm{g} / 10.1007 / \mathrm{s} 10531-009-9745-9$

Southworth, J., H. Nagendra, and D. K. Munroe. 2006. Introduction to the special issue: Are parks working? Exploring human-environment tradeoffs in protected area conservation. Applied Geography 26:87-95. http://dx.doi.org /10.1016/j.apgeog.2005.11.001

WDPA. 2010. World database on protected areas annual release. United Nations Environment Program World Conservation Monitoring Centre, International Union for the Conservation of Nature, World Commision on Protected Areas, Quebec, Canada.

Widagdo, I. 2008. Lore Lindu as one of world's biosphere reserve. Report. Balai Taman National Lore Lindu, Palu, Sulawesi, Indonesia.

WWF. 2004. Are protected areas working? WWF International, Gland, Switzerland. 
Appendix 1. Overview of management effectiveness methodologies

Many methodologies have been developed to assess the management effectiveness of PAs (Hockings 2003). They range from expert interviews ignoring ecological integrity (Bruner et al. 2001, WWF 2004) to pure satellite image analyses focusing solely on ecological integrity (Curran et al. 2004, Joppa et al. 2008, Nagendra 2008). To date, there are only few studies combining both remote sensing to analyze ecological integrity and intensive field surveys to consider institutional factors (e. g., Nagendra et al. 2005, Ostrom and Nagendra 2006). Conclusions of these studies range from "PAs are ineffective" (Curran et al. 2004), to "PAs are effective" (Joppa et al. 2008), and "PAs are effective, but not in general" (Nagendra 2008). The variety of answers indicates that PA effectiveness is complex and depends on a combination of drivers from different political levels underlining the need for integrated research approaches to understand social-ecological systems in their local, sub-national, and national context (Folke et al. 2007, Joppa et al. 2008, Hummel et al. 2011). In the case of forest PAs, measuring the impact of PAs on forest cover clearing can help assess the effectiveness of their management. Remote sensing provides a particularly effective tool and satellite image analysis is the most frequently used technique for mapping land cover change (Nagendra 2008). In order to assess the impact of a given PA on forest cover, changes within its area need to be compared to a standard area without legal protection (Nagendra 2008). Measuring the effectiveness of these areas is difficult because the amount of deforestation that would have occurred in the absence of legal protection cannot be directly observed (Andam et al. 2008). Two kinds of comparison can provide useful indicators in this regard. First, one can compare deforestation rates of areas inside and outside PAs using satellite data (e.g., Curran et al. 2004). However, these analyses can be biased because areas inside and outside the PA can differ in many characteristics, which in turn influence deforestation (Joppa et al. 2008). This is the case in situations where the PA is located in remote areas that are less accessible than the surroundings. These areas may show low rates of deforestation due to remote location rather than PA existence. Second, rates of deforestation before and after management establishment can be compared to see if creation of the PA has slowed down deforestation. This approach provides a different perspective but is limited by the general trend that deforestation is increasing over time in some areas. Thus, a combination of both approaches (i.e., deforestation rates inside and outside boundary as well as before and after management establishment) supports triangulation of the findings. Furthermore, to adequately address the multi-faceted issue of PA effectiveness, satellite image analysis should be complemented by detailed field research to provide insights into social and institutional processes that impact PA management (Southworth et al. 2006, Elmqvist et al. 2007). To date, studies focusing on South-East Asia (DeFries et al. 2005, Nagendra 2008) or Indonesia conclude that conservation endeavors, including PAs, have been unsuccessful (Curran et al. 2004, Linkie et al. 2008). 
Appendix 2. Key questions from interview guideline for villagers

Warm up

1. What is your work? What do you live on and why?

2. How long do you live here?

3. What happened in the past (ten to thirty years) in this region? What other changes did you notice?

Interviewees draw resource map; after finishing and explanation, discussion on the following topics:

4. Do you know the NP/BR?

5. Have you ever been there (in the forest)?

6. Do you know where the border of the NP/BR is?

7. What did change for you personally since this became a NP?

8. Are there any activities related to the NP/BR, in which you took part or you are taking part?

9. Are there any activities related to other organizations (NGO), in which you did take part or you are taking part?

10. Would you take part in other activities? (What kind of activities? What was it like?)

11. Do you know the people who are working for the NP/BR? Do you know what they are doing?

12. What do the people living here think of the NP/BR? Why?

13. What do you think of the NP/BR? Advantages? Disadvantages? Why?

14. Is there something about this NP/BR you would like to have changed?

15. What do you think this region will be like in 10 years?

16. What do you wish for the future (for this region)?

Key questions from interview guideline for MAB committee members

1. Warm up

1.1. Please tell us your job history; how did you get involved in this program?

2. Relation to the BR program

2.1. What are the principal issues you are currently dealing with?

3. Description of the MAB concept

3.1. What do you see as the most important function of a BR?

3.2. When, why and how was the program established?

3.3. How were the places chosen to establish a BR?

3.4. Who played an important role in the establishment process?

3.5. Who decides now if a new BR will be established?

4. Interaction of the $B R$

4.1. Who are the main actors in the area of BR?

4.2. Please describe their relationships with one another?

4.3. What are their interests with regard to the BR?

4.4. How are the NP managers involved in the MAB program?

4.5. Are there other programs on a national level concerning land management and sustainable resource use?

4.6. Who else on a national level is involved in such programs?

5. Buffer zone, and research

Activities

5.1. Are there activities/cooperation with universities and BRs in Indonesia?

5.2. What's the main topic of these activities?

5.3. Are there other activities from other sectors (ministry) related to BRs?

Status and threats of buffer zone

5.4. What do you say is the main function of the buffer zone?

5.5. What do you consider as the major threats to the buffer zone?

Sustainable development

5.6. How would you define sustainable development?

5.7. Do you have activities to promote sustainable development in the BR?

5.8. Where do these activities take place (buffer zone) and who is responsible?

5.9. Which effects do you see from these activities?

5.10. Do you have an indicator system established for these activities?

6. Implementation of the $B R$ concept

6.1. Who decides who the manager of the BR is?

6.2. Who is responsible for the management plan?

6.3. How is the interaction of BRs and MAB organized?

6.4. Do you have cooperation with other countries?

6.5. Are you in contact with regional or international MAB programs?

6.6. How are your relations to higher governmental bodies?

7. Outlook

7.1. How do you expect the BR to be in ten years?

7.2. What do you wish for your work within the program? 
1.1. Please tell us your job history; how did you get involved in this BR?

1.2. What are the principal issues you are currently dealing with?

2. Description of the $B R$

2.1. What makes the BR special/unique?

2.2. When, why and how was this BR established?

2.3. Who played an important role in the establishment process?

2.4. What do you see as the most important functions of the BR?

3. Implementation of the BR concept

3.1. How is the zonation taken into account?

3.2. Who is responsible for the management of the different zones?

3.3. What partners are you cooperating with, and how?

3.4. Who else influences the BR?

3.5. How are your relations to higher governmental bodies?

\section{Actual Situation of the BR}

\section{Ecological situation}

4.1. From ecological side, what is special for this area?

4.2. Have you noticed any change?

\section{Social situation/actors}

4.3. How many different ethnic/cultural groups live in the BR?

4.4. Please describe their relationships with one another?

4.5. How would you describe the socio-economic status?

4.6. Have you noticed any change?

4.7. What difficulties do the people within the BR face?

4.8. How are the people involved in the BR management?

4.9. What is the general attitude of the people towards nature conservation?

\section{Buffer zone}

\section{Status and threats}

5.1. What do you say in general is the main function of the buffer zone?

5.2. How would you describe the status of the buffer zone/area around the park?

5.3. What do you consider as the major threats to the buffer zone?

5.4. Are there any efforts done to minimize these threats?

Rules

5.5. What rules concerning resource use are at place in the buffer zone?

5.6. Are these rules respected?

\section{Activities}

5.7. What management activities do you have in the buffer zone/area around the park?

5.8. Which effects do you see from these activities?

5.9. In your opinion, which management actions would make sense to improve these different aspects?

\section{Sustainable development}

5.10. How would you define sustainable development?

5.11. Do you have activities to promote sustainable development in the BR?

5.12. Where do these activities take place (buffer zone) and who is responsible?

5.13. Which effects do you see from these activities?

5.14. Do you have an indicator system established for sustainable development?

6. Outlook

6.1. How do you expect this BR to be in 10 years?

6.2. What do you wish for your work in the future? 
Appendix 3. List of codes applied for interview analysis with ATLAS.ti.

After coding the interviews (open and axial), queries were performed according to the investigation level (4.1 to 4.4) cooccurring with other codes such as valuation (3.1 and 3.2) as well as themes (5.1 to 5.8).

1.1 Personal background

1.2 BR (concept) background

2.1 Before/after PA establishment

2.2 Inside/outside boundary

$2.3 \mathrm{BR}$ in general

3.1 Positive valuation

3.2 Negative valuation

4.1 National level

4.2 Sub-national level

4.3 Local level

4.4 No level specified/all levels

5.1 Implementation

5.2 Responsibility

5.3 Resources

5.4 Awareness

5.5 (alternative) Income generating

5.6 Forest cover

5.7 Participation

5.8 Leadership 